Ks. Krzysztof SORDYL, Wczesnochrześcijańskie pojęcie Boga. Polemiczne aspekty teologii Nowacjana w „De Trinitate”, Kraków 2007, Wydawnictwo WAM, ss. 396.

Nowacjan to zapomniany, a często dla wielu nieznany teolog. Jeśli już posiada się o nim jakieś informacje, to wiążą go one i kojarzą raczej z sektą, która od niego bierze swą nazwę. W historii chrześcijaństwa bywało i tak, że przekreślało się autora, ponieważ popełnił $\mathrm{w}$ jakiejś dziedzinie błąd; dotyczy to właśnie także Nowacjana.

Ten wybitny teolog III wieku doczekał się wreszcie obszernej monografii w języku polskim. Recenzowana książka to doskonały pierwszy komentarz do jego dzieła $O$ Trójcy Świętej, które ukazało się w polskiej szacie słownej w 2005 r., w znanej serii patrystycznej „Źródła Myśli Teologicznej” (35).

Nowacjan wyróżnił się tym traktatem, w którym położył walne fundamenty pod rozwój nauki trynitarnej, a także pod wyznanie wiary na Soborze w Nicei w 325 roku: skoro był on desygnowany przez papieża Fabiana na swego następcę, to niewątpliwie musiał mieć ku temu niemałe zasługi i kwalifikacje. Treść wiary była weryfikowana wobec herezji II i III w. i krystalizowała się w tym czasie na podstawie jego refleksji wyrażonej w traktacie $O$ Trójcy Świętej oraz Tertulianowego dzieła Przeciw Prakseaszowi i Przeciw Noetosowi Hipolita, do których odwołuje się ks. K. Sordyl, aby nakreślić tło omawianego dzieła i etapy rozwoju nauki dogmatu o Trójcy Świętej. Gdy jeszcze niedawno oczekiwano co najwyżej artykułu na temat obrazu Boga Ojca w De Trinitate Nowacjana, to dziś mamy opracowanie, którego przydatność będzie zapewne wykazywana w publikacjach naukowych. Fragmenty recenzji prof. dr hab. H. Pietrasa SJ i ks. dr hab. A. Barona, umieszczone z tyłu na okładce, zawierają ocenę istotnej treści pracy.

Piszący te słowa, był tłumaczem De Trinitate Nowacjana. Trud włożony w przygotowanie dzieła do druku, poprzez szukanie odniesień i studiowanie przypisów przyczynił się do rozjaśnienia omawianych w nim kwestii. W chwili oddawania przekładu do Wydawnictwa rodziła się nadzieja, że translacja przyczyni się do powstania zarówno wielu prac porównawczych, jak i nowych dysertacji dotyczących tego okresu. Rzeczywistość przerosła oczekiwania. Przykładowo wyszukiwarka internetowa Google przed kilku laty zawierała niewiele informacji o Nowacjanie, a dziś zawiera ich multum. Nie ulega wątpliwości, że także nowo wydana dysertacja przyczyni się do dalszych badań i poszukiwań.

W książce K. Sordyla mogłoby znaleźć się więcej informacji na temat Nowata, którego odróżnia się od Nowacjana: skromna wzmianka na s. 46 budzi pewien niedosyt. Również bibliografia, którą można by uznać za monumentalną, bo została zebrana na 25 stronach, nie wydaje się być pełna: nie uwzględniono w niej wszystkich artykułów, jak np. G. Jaśkiewicz, Jak katechizować o Trójcy Świętej (,Teologiczne Studia Siedleckie” 2:2005, 71-79) oraz tenże, Duch Święty w teologii III wieku na przyktadzie „De Trinitate” Nowacjana, (,Studia Teologiczne Białystok - Drohiczyn - Łomża” 23:2005, 303-309). Wydaje się to o tyle ważne, 
że np. w pierwszym artykule zwraca się uwagę na aktualność tematyki stanowiącej przedmiot zainteresowania Nowacjana, która wyraża się w sformułowaniu szeregu wskazań dotyczących kształtowania świadomości trynitarnej wiernych, by zapobiec islamizacji chrześcijaństwa, a także w dostrzeżeniu, że negacja którejś z Osób Boskich prowadzi w gruncie rzeczy do ateizmu.

Wnikliwy wstęp zawiera prawie wszystkie klasyczne jego elementy. Zabrakło w nim jednak doprecyzowania i zwerbalizowania celu pracy, chociaż teza skupia się na pojęciu Boga - czy jest ono trynitarne. Jest w nim omówiona wystarczająco biografia Nowacjana, jego dzieła, także te, które historia chciała mu przypisać. Poza tym we wstępie przedstawione są problematyka i zakres dotychczasowych badań, oraz uwagi o metodzie, strukturze i koncepcji pracy. Omówione są także thumaczenia i podstawowe opracowania, analiza źródeł i bibliografii. Podzielono ją wnikliwie wyszczególniając m.in., kto zajmował się chociażby chrystologią teofanii u Nowacjana (s. 67). Wstęp to źródło cennych informacji, bo praktycznie odzwierciedla zakres wiedzy o omawianym problemie aż do dnia dzisiejszego.

Treść książki w dalszej części składa się z pięciu rozdziałów, z których każdy zawiera podsumowanie. Pracę zamyka zakończenie, aneks oraz indeksy komentowanych tekstów biblijnych jak i postaci starożytnych. Ostatnie strony rozprawy to ogólne streszczenie i spis treści wyrażone po angielsku.

W rozdziale I jest mowa o pojęciu Boga w sporze monarchiańskim; Nowacjan nie posługiwał się tym słowem, ale treścią terminu, który wyrażał jedną władzę. W późniejszym okresie nastąpiło zafałszowanie tego terminu i kojarzono go z patrypasjanizmem, modalizmem czy sabelianizmem. Podobnie Nowacjan nie używał terminu Trójca, a jednak formułuje doktrynę, która ją wyrażała.

Rozdział II koncentruje się już wokół Pierwszej Osoby Boskiej. Reguła wiary głosząca, że Bóg Ojciec jest najdoskonalszym Stworzycielem wszystkich rzeczy, wyjaśniała wiele błędów - od doketyzmu poprzez różne odmiany gnozy i gnostycyzmu, którego liczne odmiany, jak zauważa autor pracy, rozbijały jedność historii zbawienia i potępiały materię.

Można odkryć wiele walorów tego rozdziału, jak chociażby ten, który wskazuje, gdzie u Nowacjana jest myślenie biblijne, a gdzie platońskie. Gdy mowa o poznaniu Boga i wyrażaniu tego poznania, roli rozumu i zmysłów w poznaniu, to zagadnienia te dotyczą już teorii poznania. Przez te szczegółowe punkty, praca staje się interdyscyplinarną, której spektrum obejmuje historię, teorię poznania i patrologię. Realne zaś stwierdzenia, płynące z refleksji teologicznej nad nauką Nowacjana, prowadzą do ostrzeżenia typu: „Wolność człowieka bez odniesienia do Boga może się stać siłą destrukcyjną" (s. 191).

Rozdział III, najobszerniejszy, dotyczy Syna Bożego i szerzących się błędów związanych z Jego Osobą. Warto podkreślić, że uproszczenie tłumaczenia nie oddaje wielu problemów. Zresztą należy wspomnieć, że problemy lingwistyczne były w historii często problemami teologicznymi. Figury retoryczne, czy wyrażenia, które mogą sprawiać wrażenie tautologii faktycznie odzwierciedlają specyficzny język teologiczny, który uciekał się do zestawienia słów np. homo i caro, 
które posłużyły Nowacjanowi do rozprawienia się z doketyzmem. Dobrze zostało to wychwycone i zanalizowane. Na s. 261 tegoż rozdziału jest ocena, chyba zbyt surowa, nauki rzymskiego kapłana, że nie przedstawił koncepcji ludzkiej natury Zbawiciela wprost, ale że Jego ciało było instrumentem Bożego planu.

Nie można też pisać, jak to widnieje na s. 269, że Nowacjan nie znalazł takich formuł, które pozwoliłyby opisać wewnętrzny związek Bóstwa z pełnym i działającym człowieczeństwem. Kto dziś jest w stanie lepiej opisać i wyrazić Bóstwo i człowieczeństwo Jezusa Chrystusa mimo ewolucji języka i pojęć teologicznych?

Rozdział IV dotyczy Ducha Świętego. Zostają w nim przytoczone wypowiedzi różnych teologów, zwłaszcza protestanckich, którzy interpretują kwestię Jego pochodzenia w oparciu o słowa Nowacjana. Pneumatologia nie zajmuje wiele miejsca w De Trinitate - zaledwie kilka stron, a opracowanie polemiki jest wnikliwe i wieloaspektowe (zawiera się na stronach 288-326). Ważne są stwierdzenia, choć już w innym rozdziale, że Nowacjan nie nazywał Ducha Świętego wprost Bogiem ani Osobą, ale że myślał o Nim poprawnie (s. 334), a liczy się ortodoksyjna treść, a nie słowa.

Rozdział V z kolei ukazuje relacje między Osobami Boskimi, które można określić pięknym słowem, pochodzącym z języka greckiego, oznaczającym taniec - perychoreza. Zostały one tutaj opracowane w sposób godny odnotowania. Perychoreza podkreślona została wobec herezji patrypasjanizmu i modalizmu. Przeciwstawiając się herezji monarchiańskiej Nowacjan jasno wyraża, co podkreśla ks. K. Sordyl, że Chrystus jest Tym, który wypełnia wolę Ojca. Subordynacjonizm jest u niego ortodoksyjny, służy mu do obrony monoteizmu, aby uniknąć dyteizmu (s. 350). W ten sposób Autor rozprawy powraca do monarchii, która jest klamrą spinającą dzieło, a zarazem I i V rozdział. Akcent skupia się na monarchii, a pojęcie to posłużyło Nowacjanowi do odrzucenia dyteizmu i tryteizmu (s. 360). Wyraża to paradoksalnie zdanie na s. 365, że „Nowacjan posłużył się monarchią przeciw monarchianizmowi” .

Dla tłumacza lektura tej książki jest prawdziwą ucztą intelektualną. Obiektywnie można stwierdzić, że w oparciu o wybrany i wyselekcjonowany tekst autora III wieku, odpiera się łatwo różne zarzuty. Praca w sposób może niezamierzony wskazuje na aktualność tych myśli! W książce jednak tego typu nie wszystko urasta do rangi ideału. Dyskusyjne wydaje się przedstawienie sporu Dionizych (s. 88-89), do którego później następuje odwołanie (s. 118, przyp. 175; s. 124). Brakuje także wprowadzenia i komentarza do zdania dwa razy powtórzo-

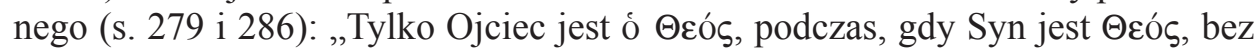
rodzajnika".

Nie należy doszukiwać się na siłę mankamentów, choć brakowało wyjaśnień teologicznych w oparciu o analizę filologiczną, jak tego próbę mamy chociażby na s. 267. Trudno w takim kontekście zrozumieć zdanie ze wstępu: „Zaprezentowane analizy filologiczne dokonywane są z punktu widzenia potrzeb teologa" (s. 75). Przecież sam Nowacjan tłumaczył zdanie „Ja i Ojciec jedno jesteśmy” (J 10, 30) 
posługując się gramatycznymi wyjaśnieniami (XXVII 149). Wrażliwość na liczne łacińskie kluczowe słowa, $\mathrm{z}$ różnymi znaczeniowymi niuansami, owocuje dobrymi wnioskami i wyjaśnieniami. Niejednokrotnie tłumacz ma po cztery słowa w nawiasie, aby w końcu zdecydować się na jedno z nich. Trzeba dostrzegać ewolucję języka, albo epokę. Termin keryks, dla przykładu, w języku greckim nie był dla wszystkich w IV wieku synonimem teologa.

Nie ulega wątpliwości, że opisanie związku obu natur w Chrystusie sprawia do dziś kłopoty. Trudności interpretacyjne, jak widać, wyjaśniane są tutaj wzorowo, poprzez analizę właśnie filologiczną, której zabrakło na innych stronach, przy innych zagadnieniach, ale dobrze, że obficie był przytaczany tekst oryginalny, aby zasmakować dzieła, o którym powiedziano, że szkoda iż jego przekład w „Źródłach Myśli Teologicznej” nie został wydany dwujęzycznie, na wzór De doctrina christiana św. Augustyna (Warszawa 1989).

Należy też podkreślić, rozpoczynając szczegółowe omawianie książki, logiczność treści De Trinitate Nowacjana, która wskazuje piszącemu plan pracy naukowej. Można przestawiać plan tylko w jednym miejscu przedkładając etymologię terminu monarchia nad jego wielowymiarowość (s. 78-79). Z kolei tytuł paragrafu 3.2.2 zatytułowanego „Logos - obraz Boga niewidzialnego” (s. 216) wydaje się być chybiony, choć zgadza się z teologią św. Pawła (Kol 1, 15; 2Kor 4, 4). Gdy jednak Nowacjan pochyla się nad tekstem o kenozie (Flp 2, 6-11) dowodzi, że Chrystus nie jest na obraz Boży, lecz w postaci Bożej, co wyraża zresztą podsumowanie (s. 286).

Niedociągnięć tego typu nie poda się w sposób wyczerpujący, ale ich zauważenie jest troską o dokładność w pracy naukowej. Nie podważają one jednak w niczym wartości naukowej recenzowanej książki. Chciałoby się dodać: pewne rzeczy są nie do uniknięcia i wiadomo, że nie zależą one nawet od samego autora. Chociażby angielskie tłumaczenie na końcu książki: jeśli przymiotnik binarian jest pisany minuskułą, to też powinno się to odnosić do Trinarian (s. 394-396); jest tractate, a wiadomo, że figuruje w świecie anglosaskim wyrażenie $A$ treatise concerning the Trinity. W spisie treści przy terminie Filiopaterism widoczny jest znak zapytania, bo thumacz prawdopodobnie zastanawiał się czy może to słowo w tej formie pozostać. Zdarzają się i literówki Phanomen, (s. 107); hyiopator (s. 206), wyrażenia typu: dalej Nowacjan kontynuuje (s. 229), powtórzenia passim o pięknej karcie eklezjologii Ducha Świętego, nawiązującej do XXIX rozdziału De Trinitate Nowacjana.

Jest to przemyślane opracowanie, które wymagało weryfikacji wielu źródeł i dotarcia do konkretnej literatury. Praca z pewnością była żmudna, ale zaowocowała dobrym odtworzeniem tła epoki, zwłaszcza w sferze problemów i kontrowersji teologicznych. Dbałość o stronę merytoryczną i formalną pracy świadczy o sumienności i zaangażowaniu jej autora. Ks. K. Sordyl podwoił objętość w stosunku do dzieła oryginalnego. Wchodząc w świat badaczy podjął się trudnego tematu i musiał przebrnąc przez gąszcz herezji, problemów i polemik.

Książka jest bardzo ciekawa, napisana w sposób przystępny dla każdego czytelnika, niezależnie od jego stopnia i godności. Wynika z niej, że wczesnochrze- 
ścijańskie pojęcie Boga zagrożone przez gnostycyzm, różne tendencje filozoficzne i nurty zostało przedstawione przez Nowacjana w sposób prosty. Posłużył się prawie 400 cytatami z Pisma Świętego. Należy z wielkim uznaniem przyjąć i wyrazić uznanie tym, którzy przyczynili się do powstania i wydrukowania tej książki. Jest ona bowiem przekonującym świadectwem tego, że także pisarze, których uważa się za kontrowersyjnych uczą nas zarówno jak poznawać Boga jak i Go miłować.

Ks. Grzegorz Jaśkiewicz - Siedlce, WSD

\section{Ks. Tadeusz GACIA, Metaforyka agonistyczna w literaturze tacińskiej chrze- ścijańskiego antyku, Kielce 2007, Wydawnictwo Jedność, ss.279.}

Bardzo dobrze został ujęty temat, również pod względem literackim, przejrzysta struktura pracy, jasno sformułowany cel naukowego zadania. Postawienie problemu interpretacyjnego pociągnęło za sobą właściwe rozplanowanie poszczególnych rozdziałów i konsekwencję metodologiczną. Precyzyjnie został wytyczony teren badawczy: dzieła piszących w języku łacińskim starożytnych autorów chrześcijańskich od końca II do poł. V wieku, a więc do czasów św. Augustyna. $\mathrm{Z}$ wielkim zatem uznaniem należy przyjąć nową pozycję ks. Tadeusza Gaci. Podjęcie tematu jest logiczną konsekwencją dotychczasowych zainteresowań Autora literaturą wczesnochrześcijańską i publikacji z tego zakresu. Autor poszerza i pogłębia dotychczasowe swoje zainteresowania. Rozprawa ks. Tadeusza Gaci ma charakter studium historycznoliterackiego. Autor koncentruje się na literackich aspektach dzieł łacińskich pisarzy wczesnochrześcijańskich, zajmuje się techniką i stylem. Dysertacja ukazuje, w jaki sposób łacińscy autorzy wczesnochrześcijańscy posługiwali się porównaniami, metaforami i innymi środkami stylistycznymi, które przejęli z agonistyki i ideę, jaką przy ich pomocy wyrażali. Agon jest w analizowanej literaturze przede wszystkim metaforą wyznania wiary podczas prześladowania, ta idea jest podkreślana u wcześniejszych autorów, ci późniejsi stosują go jako metaforę chrześcijańskiego życia.

Materiał zebrany i dokładnie zanalizowany Autor przedstawił w ośmiu rozdziałach, co wynika $\mathrm{z}$ analizy materiału literackiego. W rozdziale pierwszym: „Agonistyka w życiu i tradycji literackiej antyku” (s. 15-55) przedstawił słownictwo zarówno greckie jak i łacińskie związane z agonistyką, ideał agonistyczny i jego reminiscencje w literaturze klasycznej, transformację metaforyki agonistycznej w pismach grecko-żydowskich i najstarszej literaturze łacińskiej, wreszcie obecność odniesień do agonistyki w łacińskiej literaturze wczesnochrześcijańskiej, co umożliwiło mu przejście do analiz, które są przedmiotem kolejnych rozdziałów.

W rozdziale drugim: „Terminy, wyrażenia i peryfrazy związane z agonistyką ilustrujące publiczne wyznanie wiary" (s. 56-77). Autor wziął pod lupę filologa terminy (agon, certamen, certare, lucta, luctatus, luctamen, conluctatio, luctari, 